\title{
SCIENTIFIC REPORTS

\section{OPEN Efficient whole-cell catalysis for 5-aminovalerate production from L-lysine by using engineered Escherichia coli with ethanol pretreatment}

\begin{abstract}
Jie Cheng $\oplus^{1 *}$, Qing Luo ${ }^{1}$, Huaichuan Duan ${ }^{1}$, Hao Peng ${ }^{2}$, Yin Zhang ${ }^{1}$, Jianping Hu ${ }^{1 *} \& \mathrm{Yao} \mathrm{Lu}^{3 *}$
Microorganisms can utilize biomass to produce valuable chemicals, showing sustainable, renewable and economic advantages compared with traditional chemical synthesis. As a potential five-carbon platform polymer monomer, 5 -aminovalerate has been widely used in industrial fields such as clothes and disposable goods. Here we establish an efficient whole-cell catalysis for 5 -aminovalerate production with ethanol pretreatment. In this study, the metabolic pathway from L-lysine to 5 -aminovalerate was constructed at the cellular level by introducing L-lysine $\alpha$-oxidase. The newly produced $\mathrm{H}_{2} \mathrm{O}_{2}$ and added ethanol both are toxic to the cells, obviously inhibiting their growth. Here, a promising strategy of whole-cell catalysis with ethanol pretreatment is proposed, which greatly improves the yield of 5-aminovalerate. Subsequently, the effects of ethanol pretreatment, substrate concentration, reaction temperature, $\mathrm{pH}$ value, metal ion additions and hydrogen peroxide addition on the wholecell biocatalytic efficiency were investigated. Using $100 \mathrm{~g} / \mathrm{L}$ of L-lysine hydrochloride as raw material, $50.62 \mathrm{~g} / \mathrm{L}$ of 5 -aminovalerate could be excellently produced via fed-batch bioconversion with the yield of $0.84 \mathrm{~mol} / \mathrm{mol}$. The results show that a fast, environmentally friendly and efficient production of 5-aminovalerate was established after introducing the engineered whole-cell biocatalysts. This strategy, combined with ethanol pretreatment, can not only greatly enhance the yield of 5 -aminovalerate but also be applied to the biosynthesis of other valuable chemicals.
\end{abstract}

With the increasingly severe global environmental pollution and petroleum shortages, energy security has been widely concerned, and great efforts have been made to develop bio-based chemicals with renewable feedstock ${ }^{1}$. 5 -aminovalerate (5AVA) is a non-proteinogenic amino acid that could be used as a potential, promising and valuable precursor for producing $\delta$-valerolactam ${ }^{2}$, glutarate ${ }^{3}$ and nylon 5 fibers and resins ${ }^{4}$. It also could be used for synthesis of 5-hydroxyvalerate ${ }^{5}, 1,5$-pentanediol and other valuable chemicals. 5AVA could be manufactured from L-lysine (L-lys), which could be produced 2.2 million tons per year ${ }^{3,6}$. In view of the important applications of 5AVA in the field of synthesis, it is necessary to put forward relatively higher requirement for the development of the biotechnological 5AVA production.

In fact, the 5AVA production is closely related to the biological metabolism of L-lysine 7 . 5AVA is mainly synthetized through the coupled system of L-lys 2-monooxygenase (DavB) and 5-aminovaleramide amidohydrolase $(\mathrm{DavA})^{8}$. Jorge et al. found that L-lys could be decarboxylated to form cadaverine by L-lys decarboxylase (CadA), then to 5AVA by consecutive transamination and oxidation ${ }^{9}$. Recently, Cheng et al. reported that L-lys hydrochloride (L-lys $\mathrm{HCl}$ ) could be oxidative decarboxylated by L-lys $\alpha$-oxidase (RaiP) from Scomber japonicas to produce 5AVA in Escherichia coli (E. coli $)^{10}$. Based on these three basic synthetic routes converting L-lys to 5AVA, the three related bioproduction processes (i.e., microbial fermentation, enzymatic catalysis, and whole-cell methods) have

${ }^{1}$ Key Laboratory of Coarse Cereal Processing of Ministry of Agriculture and Rural Affairs, College of Pharmacy and Biological Engineering, Chengdu University, Chengdu, 610106, P. R. China. ${ }^{2}$ College of Chemistry and Chemical Engineering, Yangtze Normal University, Chongqing, 408100, P. R. China. ${ }^{3}$ College of Biological and Chemical Engineering, Guangxi University of Science and Technology, Liuzhou, 545006, P. R. China. *email: jcheng@cqu.edu. cn; hjpcdu@163.com; 41039639@qq.com 


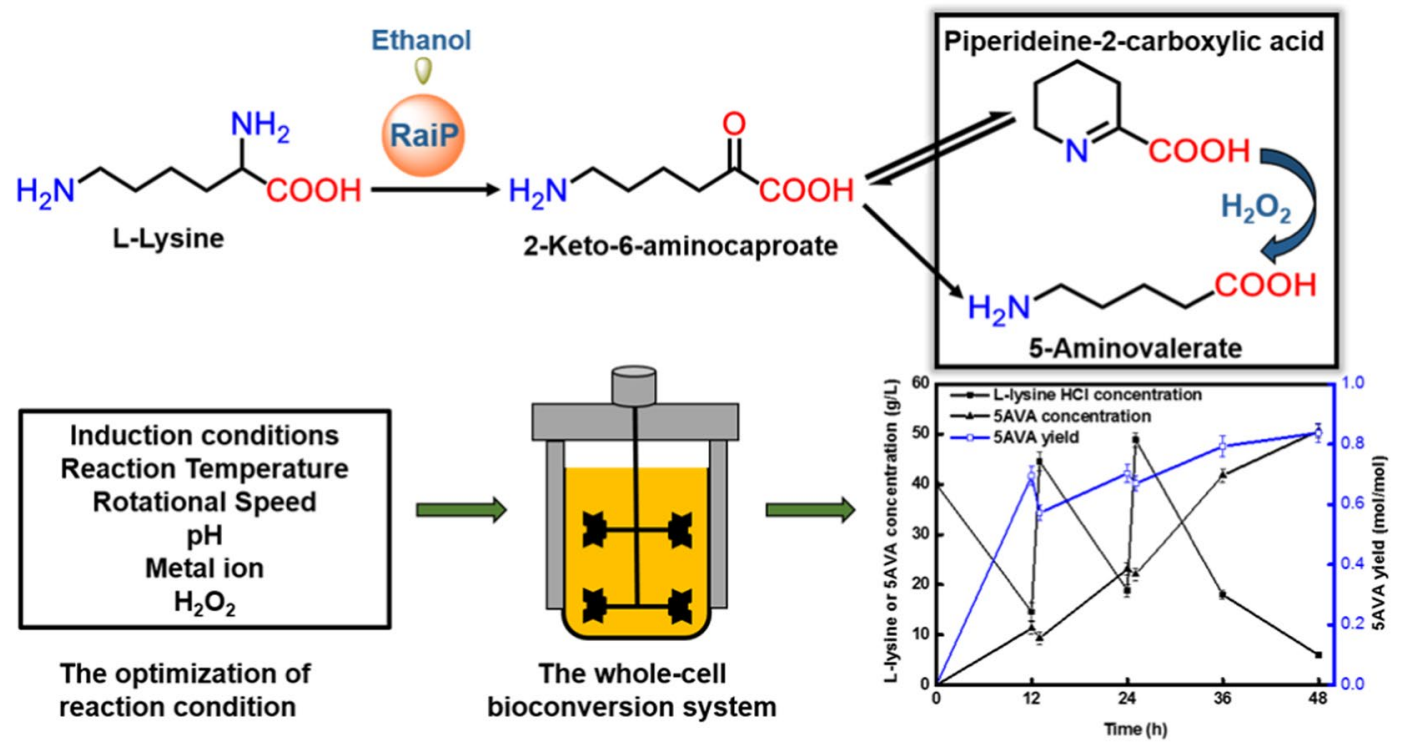

Figure 1. E. coli whole-cell overexpressing RaiP system with ethanol pretreatment converting L-lysine to 5-aminovalerate.

been widely explored. For microbial fermentation, while DavA and DavB both were overexpressed in WL3110 and $3.6 \mathrm{~g} / \mathrm{L}$ of 5 AVA could be generated ${ }^{11}$. The engineered Corynebacterium glutamicum (C. glutamicum) strain under a synthetic $\mathrm{H}_{36}$ promoter could produce $33.1 \mathrm{~g} / \mathrm{L}$ of $5 \mathrm{AVA}^{12}$. Putrescine transaminase (PatA), CadA and $\gamma$-aminobutyraldehyde dehydrogenase (PatD) were overexpressed in C. glutamicum, and 5.1 g/L of 5AVA was gained from glucose and alternative carbon sources ${ }^{9}$, as well as $28 \mathrm{~g} / \mathrm{L}$ of $5 \mathrm{AVA}$ from a de novo bioproduction process with gabT gene deletion ${ }^{13}$. In Cheng's research, the addition of $4 \%(\mathrm{v} / \mathrm{v})$ ethanol effectively enhanced the level of RaiP protein expression, which could increase the titer of 5AVA to $29.12 \mathrm{~g} / \mathrm{L}^{10}$. For the enzymatic catalysis of 5AVA, Liu et al. found that $20.8 \mathrm{~g} / \mathrm{L}$ of 5 AVA could be produced using the coupled system of purified DavB and DavA ${ }^{5}$. Under the catalysis of RaiP immobilized on a solid support, $13.4 \mathrm{~g} / \mathrm{L}$ of $5 \mathrm{AVA}$ could be produced after 5 days ${ }^{14}$. In addition, an artificial iterative carbon-chain-extension cycle was constructed to generate 5AVA, a non-natural straight-chain amino acid $^{15}$. Objectively, microbial fermentation has the disadvantages of long cycle, impure metabolites and complex process. The use of purified enzymes often leads to an increased production $\operatorname{costs}^{16}$.

Whole-cell biocatalysis has unique advantages, such as simple component of the reaction mixture, higher selectivity, highly catalytic activity and cost-effectiveness, etc. It has been widely used in the biosynthesis of 5AVA and other value-added chemicals ${ }^{17}$. In fact, whole-cell biocatalysis was considered as a competitive industrial process $^{18}$, based on which Li et al. successfully obtained $24.8 \mathrm{~g} / \mathrm{L}$ of $\beta$-alanine ${ }^{19}$. Cui et al. evaluated the effects of gene knockout on the production of glutathione by whole-cell catalysis ${ }^{20}$, and successfully prepared $103.1 \mathrm{~g} / \mathrm{L}$ of 5 AVA in the W3110/DavA-DavB ${ }^{21}$. Park et al. developed a novel process producing $90.59 \mathrm{~g} / \mathrm{L}_{\text {of }} 5 \mathrm{AVA}^{22}$. Li's work showed that the overexpression of L-lys specific permease (LysP) enhanced 5AVA production, and $63.2 \mathrm{~g} / \mathrm{L}$ of such compound could be successfully obtained using the whole-cell catalysis strategy ${ }^{23}$.

Bacterial strains often be engineered to express recombinant proteins. The expression of proteins is often induced by isopropyl $\beta$-D-thiogalactopyranoside (IPTG) in strain expression system. However, the expression level of proteins is still relatively low ${ }^{24}$. Effective strategies for improving expression level of proteins were developed, include the optimization of the host strains, vector, culture medium and gene sequences, as well as the addition of ethanol ${ }^{25}$. Ethanol has been demonstrated to works with T7 or T5 promoters, and a relatively higher level of protein expression was observed with the addition of $2 \%-4 \%$ ethanol ${ }^{24}$. In Chhetri' research, the addition of $3 \%$ ethanol could not only improve the expression level of the heterogeneous amyloid-beta peptide ${ }^{25}$, but also increase the enzymatic activity by 5 -fold ${ }^{26}$. Cheng et al. also found that the addition of $4 \%$ ethanol has a 3 -fold increase in production of $5 \mathrm{AVA}^{10}$. Importantly, the maltose $\mathrm{ABC}$ transporter was revealed to be the main regulatory route activated to enhance the expression of heterologous proteins by ethanol ${ }^{27}$. Therefore, the ethanol pretreatment has proved to be a potential, environmentally friendly and efficient method to enhance the level of enzyme expression, and further to improve the yield of related reaction products ${ }^{28}$.

In this work, E. coli CJ02 overexpressed RaiP from Scomber japonicasused (CJ02RaiP) as whole-cell biocatalysts was constructed, sequentially followed by optimizing the concentration of ethanol pretreatment, reaction temperature, $\mathrm{pH}$ value, the additions of metal ion and hydrogen peroxide (see Fig. 1). Under optimal conditions, whole-cell biocatalysts CJ02RaiP exhibiting a better catalytic activity was finally achieved.

\section{Results and Discussion}

The effect of whole-cell catalyst with ethanol pretreatment on 5AVA production. In this work, two strategies-substrate L-lys $\mathrm{HCl}$ addition and cadA knockout-were conducted to increase the utilization of L-lys. Our previous studies have demonstrated that $\mathrm{L}$-lys $\mathrm{HCl}$ is a better substrate to produce $5 \mathrm{AVA}^{10}$ and L-pipecolic acid (L-PA) than L-lys ${ }^{29}$, respectively increasing the titer of $5 \mathrm{AVA}^{10}$ by $24 \%$ and L-PA ${ }^{29}$ by $21 \%$. Lys 


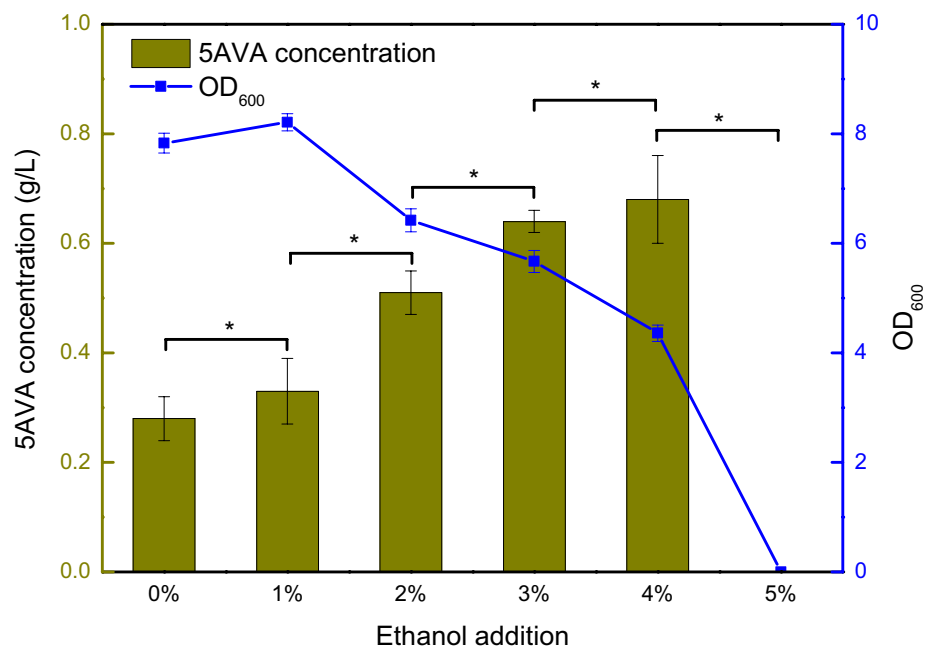

Figure 2. 5AVA titer by whole-cell biocatalysts CJ02RaiP with ethanol pretreatment of different concentration at $37^{\circ} \mathrm{C}, 250 \mathrm{rpm}$ and $\mathrm{pH} 8.0$ after $12 \mathrm{~h} .5 \mathrm{~g} / \mathrm{L}$ of L-lysine $\mathrm{HCl}$ was as substrate and the $\mathrm{OD}_{600}$ was 40 . Various ethanol concentration of $0 \%, 1 \%, 2 \%, 3 \%, 4 \%$ and $5 \%$ were investigated. Data are means \pm SD $(n=3)$. Statistics were performed by the two-tailed Student's $t$-test. ${ }^{*} p<0.05$; ns, not significant.

could be degraded to cadaverine by $\mathrm{CadA}^{30}$, which was knocked out to increase the flus to 5AVA. If not specified, $\mathrm{L}$-lys was replaced by $\mathrm{L}$-lys $\mathrm{HCl}$ in this work.

Figure 2 shows the effects of whole-cell biocatalysts CJ02RaiP on the production of 5AVA at different ethanol concentration of pretreatment, and other reaction conditions are $5 \mathrm{~g} / \mathrm{L}$ of L-lys $\mathrm{HCl}, 37^{\circ} \mathrm{C}$ and $250 \mathrm{rpm}$ for $12 \mathrm{~h}$ (see Fig. 2). When the concentration of ethanol pretreatment was $1 \%(\mathrm{v} / \mathrm{v}), 0.33 \mathrm{~g} / \mathrm{L}$ of 5 AVA was produced after $12 \mathrm{~h}$, which was $17.86 \%$ higher than that without ethanol pretreatment as control. When the concentration of ethanol pretreatment was increased to $2 \%, 3 \%$ and $4 \%$, the titer of $5 A V A$ reached $0.51 \mathrm{~g} / \mathrm{L}, 0.62 \mathrm{~g} / \mathrm{L}$ and $0.68 \mathrm{~g} / \mathrm{L}$, with the increase rates of $82.14 \%, 121.43 \%$ and $142.86 \%$, respectively. However, when continuing to augment the concentration of ethanol pretreatment to $5 \%$, the cell growth was unexpectedly significantly inhibited. Hence, the optimal concentration of ethanol pretreatment was set as $4 \%$. It has been proved enhancing protein expression contributes to improving the titer of production ${ }^{26,31}$. Ethanol could also exhibit divergent effect on inclusion body formation ${ }^{32}$. As shown in Fig. 3, the addition of $4 \%$ ethanol increased the expression of RaiP protein by about 30\% compared with the absence of ethanol. In this work, whole-cell catalysts with ethanol pretreatment did improve the production of 5AVA significantly.

Optimization of whole-cell transformation conditions. Reaction temperature. To enhance the biocatalytic efficiency, the optimal reaction temperature was discussed here. Figure 4A shows the 5AVA production catalyzed by whole-cell biocatalysts CJ02RaiP with $4 \%$ ethanol pretreatment at different temperature, $5 \mathrm{~g} / \mathrm{L}$ of $\mathrm{L}-$ lys $\mathrm{HCl}, \mathrm{pH} 8.0$ and $250 \mathrm{rpm}$ for $12 \mathrm{~h}$. It was shown that the reaction temperature ranging from 16 to $58^{\circ} \mathrm{C}$ had obviously influence on 5AVA production. The whole-cell biocatalysts CJ02RaiP could only generate $0.37 \mathrm{~g} / \mathrm{L}$ of $5 \mathrm{AVA}$ at $16^{\circ} \mathrm{C}$. As the reaction temperature increased, the titer of 5AVA increased gradually. When the reaction temperature was $37^{\circ} \mathrm{C}$, the titer of 5 AVA was $0.68 \mathrm{~g} / \mathrm{L}$. Notably, only $0.18 \mathrm{~g} / \mathrm{L}$ of $5 \mathrm{AVA}$ was obtained at $58^{\circ} \mathrm{C}$, implying that the whole-cell catalytic activity decreased to very low levels at high temperature. The results were consistent with the character of most enzymes, that is, the function curve of enzyme activity to temperature is an inverted bell shaped. Hence, $37^{\circ} \mathrm{C}$ was set as the optimal reaction temperature.

Rotational speed. The whole-cell catalysis was executed in the flasks with rotation, allowing the permeation of the oxygen in the air. Here, $\mathrm{O}_{2}$ is the electron acceptor of the oxidative, and $\mathrm{NH}_{3}$ is produced as a byproduct for enzyme RaiP to transform L-lys HCl to 5AVA. Obviously, rotational speed could partly determine the production of 5AVA by affecting the dissolved oxygen. Figure $4 \mathrm{~B}$ shows the $5 \mathrm{AVA}$ production performed at different rotational speed, $5 \mathrm{~g} / \mathrm{L}$ of L-lys $\mathrm{HCl}, \mathrm{pH} 8.0$ and $37^{\circ} \mathrm{C}$ for $12 \mathrm{~h}$. With the increase of rotational speed, the titer of 5AVA is slightly increased. When the stirring rate was $100 \mathrm{rpm}$, the titer of $5 \mathrm{AVA}$ reached $0.48 \mathrm{~g} / \mathrm{L}$; when the rate become $200 \mathrm{rpm}$, the corresponding titer increased to $0.64 \mathrm{~g} / \mathrm{L}$; as the rotation speed continued to increase, there was no significant difference in the titer of 5AVA. Thus, $200 \mathrm{rpm}$ was adopted in the subsequent experiments.

pH value. To achieve a higher titer of product, the $\mathrm{pH}$ values during the 5AVA production were also discussed. The relevant reaction conditions were the $50 \mathrm{mM}$ PKB buffer containing $5 \mathrm{~g} / \mathrm{L}$ of L-lys $\mathrm{HCl}$, the $\mathrm{pH}$ values ranged from 6.0 to 10.0 , reaction temperature of $37^{\circ} \mathrm{C}$, culture time of $12 \mathrm{~h}$ at $200 \mathrm{rpm}$ shaking. As shown in Fig. $4 \mathrm{C}$, the optimal $\mathrm{pH}$ value for production of 5AVA was 8.0. It can be seen that the conditions of excessive acid and alkali are not conductive to the bioconversion from $\mathrm{L}$-lys $\mathrm{HCl}$ to $5 \mathrm{AVA}$, thus the subsequent experiments were executed at $\mathrm{pH}$ value of 8.0. 


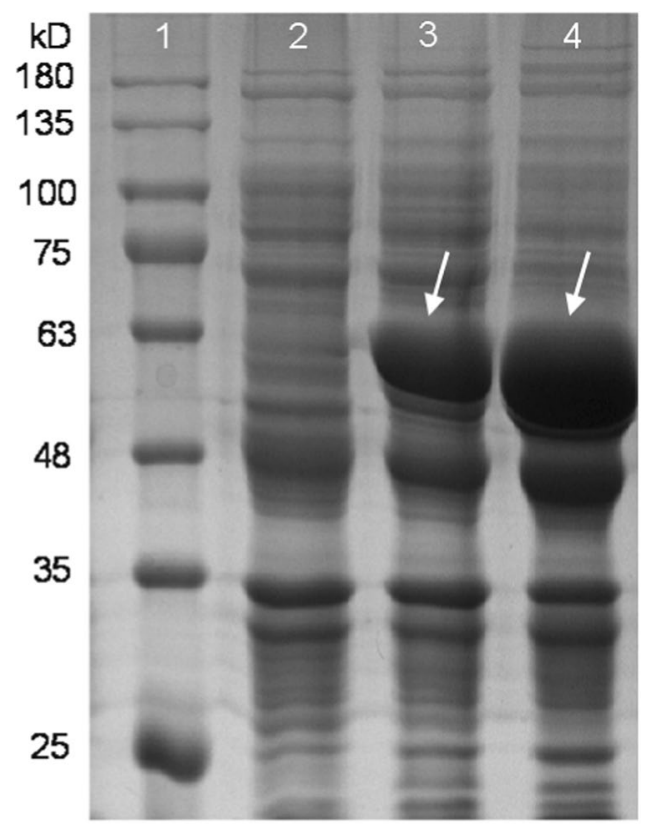

Figure 3. Expression analysis of RaiP. Protein samples were separated by $12 \%$ SDS-PAGE and stained with coomassie brilliant blue. Lane 1, molecular weight markers (kDa); Lane 2, RaiP noninduced control; Lane 3, RaiP induced in the absence of ethanol; Lane 4, RaiP induced in the presence of $4 \%$ ethanol. The expression was induced with $0.5 \mathrm{mM}$ IPTG.

Metal ions. Figure 4D shows the influence of metal ions on the 5AVA production in whole-cell biocatalysts CJ02RaiP with $4 \%$ ethanol pretreatment. As shown in Fig. 4D, the addition of $3 \mathrm{mM} \mathrm{Mg}^{2+}$ exhibited a positive effect on the 5AVA production with 0.19 -fold higher, and the titer of 5AVA increased from 0.68 to $0.81 \mathrm{~g} / \mathrm{L}$. There is no significant variation in the catalytic activity by adding $\mathrm{Mo}^{2+}, \mathrm{Zn}^{2+}$ or $\mathrm{Ca}^{2+}$, while the addition of $\mathrm{Fe}^{3+}, \mathrm{Fe}^{2+}, \mathrm{Co}^{2+}$ or $\mathrm{Cu}^{2+}$ exhibited negative influence. Specially, the $\mathrm{Cu}^{2+}$ and $\mathrm{Co}^{2+}$ both significantly decreased the catalytic activity of whole-cell biocatalysts CJ02RaiP (see Fig. 4D). Nevertheless, the addition of $\mathrm{Mg}^{2+}$ could significantly improve the activity of whole-cell catalysts CJ02RaiP. Positive effect of $\mathrm{Mg}^{2+}$ was reported in phosphoenolpyruvate carboxylase ${ }^{33}$, malate dehydrogenase ${ }^{34}$ or pyruvate carboxylase ${ }^{35}$, where exogenous $\mathrm{Mg}^{2+}$ ion addition enhanced the enzyme activity to produce succinate. As a substrate activator ${ }^{36}, \mathrm{Mg}^{2+}$ might be associated with organic cofactors to form stable units like our study. However, in a previous study, the addition of $\mathrm{Zn}^{2+}$ could also improve the enzyme activity about 1.1 -fold at the concentration of $1 \mathrm{mM}^{37}$. It is speculated that low concentration ( $1 \mathrm{mM}$ ) of $\mathrm{Zn}^{2+}$ could improve the activity of RaiP, whereas high concentration $(3 \mathrm{mM})$ inhibited its enzyme activity.

The effect of $\mathrm{H}_{2} \mathrm{O}_{2}$ as oxidant on the 5AVA production. The addition time of $\mathrm{H}_{2} \mathrm{O}_{2}$ was also optimized in this study. $1.27 \mathrm{~g} / \mathrm{L}$ of $5 \mathrm{AVA}$ could be achieved by adding $5 \mathrm{mM} \mathrm{H}_{2} \mathrm{O}_{2}$ after $8 \mathrm{~h}$ reaction, increasing by $19.81 \%$ compared with 0 h. However, the titer of $5 \mathrm{AVA}$ was decreased if $\mathrm{H}_{2} \mathrm{O}_{2}$ continued to be added later. Figure 5 shows the effects of $\mathrm{H}_{2} \mathrm{O}_{2}$ on the 5AVA production by the whole-cell biocatalysts CJ02RaiP with $4 \%$ ethanol pretreatment. After the addition of $5 \mathrm{mM} \mathrm{H}_{2} \mathrm{O}_{2}$, whole-cell catalysts CJ02RaiP could produce $1.27 \mathrm{~g} / \mathrm{L}$ of 5 AVA after $12 \mathrm{~h}$, which increased by about $66.67 \%$ compared with the absent of $\mathrm{H}_{2} \mathrm{O}_{2}$ addition. When $10 \mathrm{mM} \mathrm{H}_{2} \mathrm{O}_{2}$ was added, the titer of 5AVA significantly increased to $1.52 \mathrm{~g} / \mathrm{L}$, with a $5 \mathrm{AVA}$ titer increase of $87.65 \%$. The results indicated that the addition of $\mathrm{H}_{2} \mathrm{O}_{2}$ could favor the reaction to 5AVA and increase its metabolic flux. When continuing to increase the concentration of $\mathrm{H}_{2} \mathrm{O}_{2}$ addition, the titer of 5AVA was decreased. High concentration of $\mathrm{H}_{2} \mathrm{O}_{2}$ might reduce the enzyme activity of RaiP. It is in accordance with the previous reported findings of Cheng et al., where a higher concentration of 5AVA could be obtained by adding $\mathrm{H}_{2} \mathrm{O}_{2}$ after fermentation for $8 \mathrm{~h}^{10}$. High concentration of $\mathrm{H}_{2} \mathrm{O}_{2}$ could significantly inhibit enzyme activity of RaiP in this work. Hence, we proposed a strategy that high concentration of $\mathrm{H}_{2} \mathrm{O}_{2}$ was added after $8 \mathrm{~h}$ reaction of CJ02RaiP helping to accumulate intermediate 2-keto-6-aminocaproate (2K6AC) in the biocatalytic process. In order to eliminate the negative effects in the growth process, adding $\mathrm{H}_{2} \mathrm{O}_{2}$ as oxidant at the later stage of growth could be an alternative method.

Whole-cell catalysis and sale-up bioconversion of 5AVA production. The whole-cell biocatalysis from L-lys $\mathrm{HCl}$ to 5AVA was conducted under the optimal conditions to investigate the feasibility of CJ02RaiP as a $5 \mathrm{AVA}$ producer in a $2 \mathrm{~mL}$ reactor supplemented with $5 \mathrm{~g} / \mathrm{L}$ of L-lys $\mathrm{HCl}$. The whole-cell biocatalyst CJ02RaiP could consume more than $60 \%$ of the L-lys $\mathrm{HCl}$ after $8 \mathrm{~h}$ (see Fig. $6 \mathrm{~A}$ ). After $24 \mathrm{~h}$, the reaction went to completion and $2.71 \mathrm{~g} / \mathrm{L}$ of 5AVA was produced. The yield of 5AVA was greatly improved during the biocatalytic process (see Fig. 6A), due to that L-lys $\mathrm{HCl}$ was firstly converted into intermediate $2 \mathrm{~K} 6 \mathrm{AC}$ catalyzed by RaiP, and then oxidatively decarboxylated into 5AVA in the presence of the oxidant $\mathrm{H}_{2} \mathrm{O}_{2}$. 

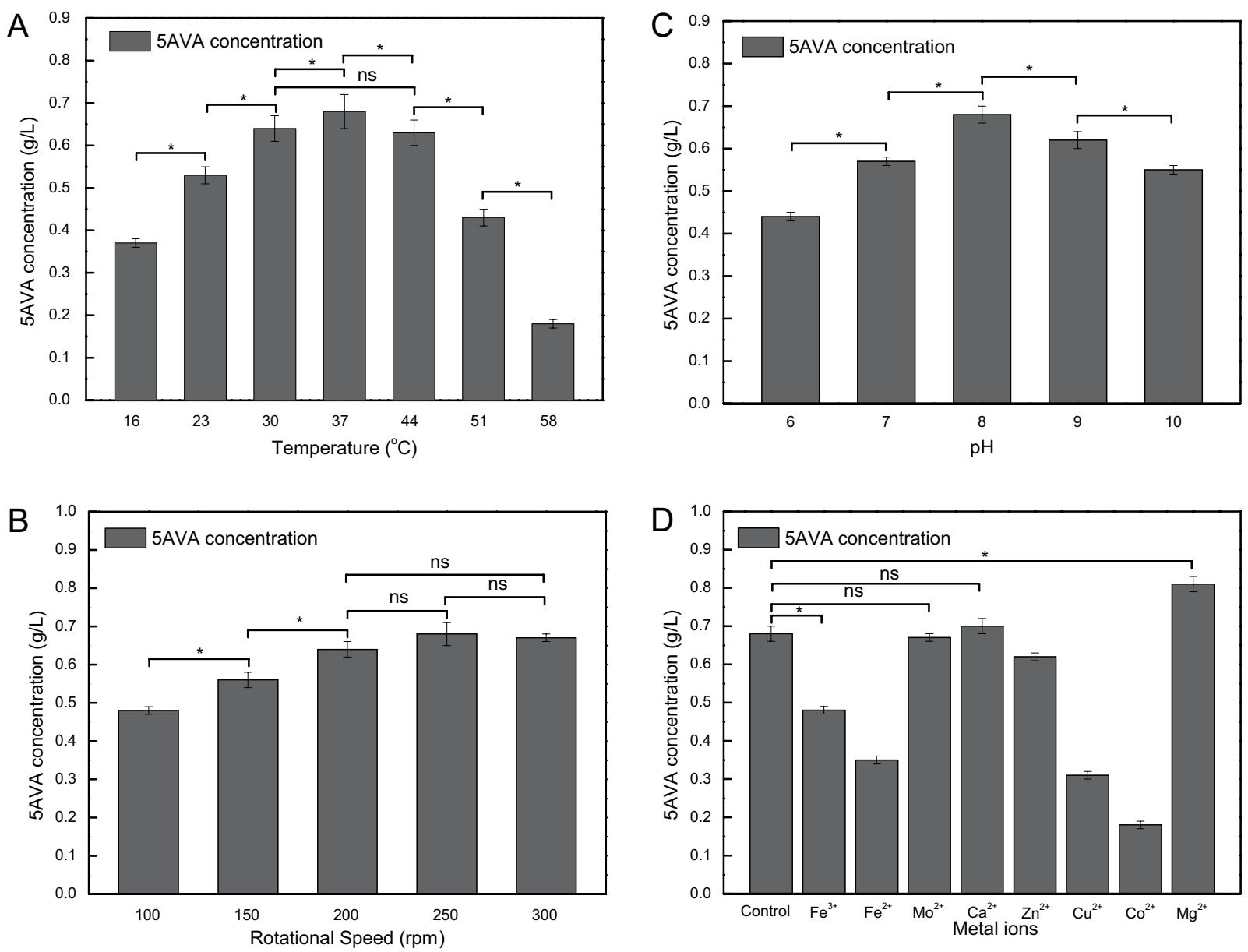

Figure 4. (A) Biosynthesis of 5AVA achieved via whole-cell biocatalysts CJ02RaiP with $4 \%$ ethanol pretreatment at different temperature, $5 \mathrm{~g} / \mathrm{L} \mathrm{L}$-lysine $\mathrm{HCl}, 250 \mathrm{rpm}$ and $\mathrm{pH} 8.0$ for $12 \mathrm{~h}$. Various temperature of $16^{\circ} \mathrm{C}, 23^{\circ} \mathrm{C}, 30^{\circ} \mathrm{C}, 37^{\circ} \mathrm{C}, 44^{\circ} \mathrm{C}, 51^{\circ} \mathrm{C}$ and $58^{\circ} \mathrm{C}$ were investigated. (B) Biosynthesis of $5 \mathrm{AVA}$ achieved via whole-cell biocatalysts CJ02RaiP with $4 \%$ ethanol pretreatment at different rotational speed, $5 \mathrm{~g} / \mathrm{L} \mathrm{L}$-lysine $\mathrm{HCl}$, $37^{\circ} \mathrm{C}$ and $\mathrm{pH} 8.0$ for $12 \mathrm{~h}$. Various rotational speed of $100 \mathrm{rpm}, 150 \mathrm{rpm}, 200 \mathrm{rpm}, 250 \mathrm{rpm}$ and $300 \mathrm{rpm}$ were investigated. Data are means $\pm S D(n=3)$. Statistics were performed by the two-tailed student t-test. * $p<0.05$; ns, not significant. C: Biosynthesis of 5AVA achieved via whole-cell biocatalysts CJ02RaiP with $4 \%$ ethanol pretreatment at different $\mathrm{pH}, 5 \mathrm{~g} / \mathrm{L} \mathrm{L}$-lysine $\mathrm{HCl}, 37^{\circ} \mathrm{C}$ and $200 \mathrm{rpm}$ for $12 \mathrm{~h}$. Various $\mathrm{pH}$ of $6,7,8,9$ and 10 were investigated. D: The effect of metal ions on 5AVA production were investigated with $4 \%$ ethanol pretreatment at $5 \mathrm{~g} / \mathrm{L} \mathrm{L}$-lysine $\mathrm{HCl}, 37^{\circ} \mathrm{C}, \mathrm{pH} 8.0$ and $200 \mathrm{rpm}$ for $12 \mathrm{~h}$. Various metal ions of $\mathrm{Mg}^{2+}, \mathrm{Mo}^{2+}, \mathrm{Ca}^{2+}, \mathrm{Zn}^{2+}, \mathrm{Fe}^{2+}$, $\mathrm{Fe}^{3+}, \mathrm{Cu}^{2+}$ and $\mathrm{Co}^{2+}(3 \mathrm{mM})$ were investigated. Data are means $\pm \mathrm{SD}(\mathrm{n}=3)$. Statistics were performed by the two-tailed Student's $t$-test. * $p<0.05$; ns, not significant.

To further examine the industrial potential of CJ02RaiP, a fed-batch strategy was adopted in a $400 \mathrm{~mL}$ reactor to enhance the 5AVA production. $11.35 \mathrm{~g} / \mathrm{L}$ of 5AVA was produced after $12 \mathrm{~h}$ (see Fig. $6 \mathrm{~B}$ ), where $30 \mathrm{~g} / \mathrm{L}$ of L-lys $\mathrm{HCl}$ was added into the reactor to maintain high-efficiency bioconversion; 5AVA titer increased to $23.12 \mathrm{~g} / \mathrm{L}$ at $24 \mathrm{~h} ; 50.62 \mathrm{~g} / \mathrm{L}$ of $5 \mathrm{AVA}$ with a yield of $0.84 \mathrm{~mol} / \mathrm{mol}$ was obtained at $48 \mathrm{~h}$ by adding another $30 \mathrm{~g} / \mathrm{L}$ of L-lys $\mathrm{HCl}$. At this point, the production of 5AVA reached equilibrium, no obvious increases in 5AVA production were obtained after $48 \mathrm{~h}$. At the end of the reaction, there were $6.05 \mathrm{~g} / \mathrm{L}$ of Lys $\mathrm{HCl}$ and a little intermediate $2 \mathrm{~K} 6 \mathrm{AC}$ remained.

Whole cell catalysis could usually obtain a higher yield ${ }^{17} .63 .2 \mathrm{~g} / \mathrm{L}$ of 5 AVA was produced by whole cell catalysis with a yield of $0.75 \mathrm{~g} / \mathrm{g}^{23}$. Compared with microbial fermentation in Cheng's study ${ }^{10}$, whole-cell catalysis could produce a higher titer from 29.12 to $50.62 \mathrm{~g} / \mathrm{L}$, and shorten the reaction time from 72 to $48 \mathrm{~h}$. In addition, the produced $\mathrm{H}_{2} \mathrm{O}_{2}$ and added ethanol during the fermentation process markedly inhibited the cell growth, resulting in the highest $\mathrm{OD}_{600}$ of only $41^{10}$. Satisfactorily, whole-cell catalysis is free of cell growth restrictions, and $\mathrm{OD}_{600}$ could reach up to 80 , thus further improving 5AVA production. In fact, the high yield of 5AVA is related the two-step reaction mechanism: (1) the intermediate $2 \mathrm{~K} 6 \mathrm{AC}$ was heavily accumulated by RaiP; (2) hydrogen peroxide served as oxidant to form 5AVA through decarboxylation and oxidation. 


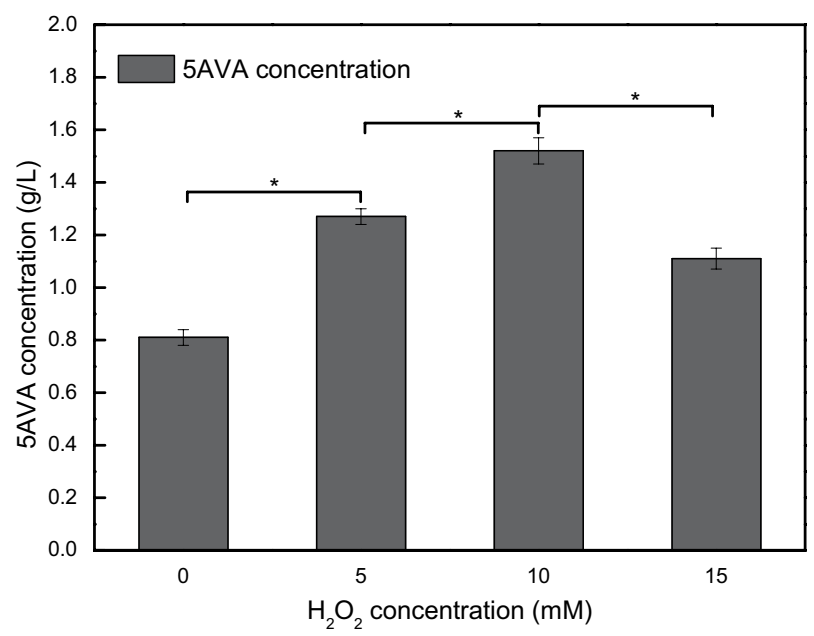

Figure 5. 5AVA production achieved by engineered whole-cell biocatalysts CJ02RaiP in the presence of different $\mathrm{H}_{2} \mathrm{O}_{2}$ concentrations. The experiments were conducted at $5 \mathrm{~g} / \mathrm{L}$ L-lysine $\mathrm{HCl}, 4 \%$ ethanol pretreatment, $37^{\circ} \mathrm{C}, 3 \mathrm{mM} \mathrm{Mg}^{2+}$, $\mathrm{pH} 8.0$ and $200 \mathrm{rpm}$ for $12 \mathrm{~h}$. Various $\mathrm{H}_{2} \mathrm{O}_{2}$ concentrations $(0,5,10$ and $15 \mathrm{mM})$ were added after reaction $8 \mathrm{~h}$. Values and error bars represent the mean and the standard deviation of triplicate cultivations. Statistics were performed by the two-tailed Student's $t$-test. * $p<0.05$; ns, not significant.

\section{Conclusions}

A green whole-cell biocatalytic production for the 5AVA was established in this work. CJ02RaiP, as an efficient whole-cell biocatalyst, could produce $0.81 \mathrm{~g} / \mathrm{L}$ of $5 \mathrm{AVA}$ from $5 \mathrm{~g} / \mathrm{L}$ of $\mathrm{L}$-lys $\mathrm{HCl}$ with $4 \%$ ethanol pretreatment after reaction $12 \mathrm{~h}$. The yield of $5 \mathrm{AVA}$ production with ethanol pretreatment was $189.29 \%$ higher than that without pretreatment. A titer of $1.52 \mathrm{~g} / \mathrm{L}$ of 5AVA was obtained after reaction $12 \mathrm{~h}$ using whole-cell biocatalysts CJ02RaiP with $4 \%$ ethanol pretreatment and $10 \mathrm{mM} \mathrm{H}_{2} \mathrm{O}_{2}$, which increased 5AVA production by $87.65 \%$ than that in the absence of $\mathrm{H}_{2} \mathrm{O}_{2}$. After a series of process optimizations (i.e., pretreatment with $4 \%$ ethanol, and the addition of $10 \mathrm{mM} \mathrm{H}_{2} \mathrm{O}_{2}$ after reaction $48 \mathrm{~h}$, etc.), $50.62 \mathrm{~g} / \mathrm{L}$ of 5 AVA can be obtained based on this engineered whole-cell biocatalytic system. The constructed whole-cell biocatalyst system with ethanol pretreatment shows the advantages of renewable substrate, simple component of the reaction mixture, higher titer and environmental friendliness. It has important application values for large-scale production of 5-aminovalerate and other valuable chemicals.

\section{Materials and Methods}

Microorganisms and culture conditions. E. coli DH5 $\alpha$ was used for the propagation of plasmids, $E$. coli BL21 (DE3) and its derivative both used for 5AVA production, and vector pET21a for protein expression. The nucleotide sequence of the synthetic and optimized raiP gene is available in the GenBank database (Refseq accession No. MG423617) ${ }^{29}$. The raiP from Scomber japonicas with BamHI and NdeI restriction sites was ligated into the vector pET21a to form pCJ01. The gene cadA was knocked out in E. coli BL21 (DE3) to obtained strain ML03 using the two steps of homologous ${ }^{10}$. The strain ML 03 harboring plasmid pCJ01 was named CJ02. All the resulting strains were cultured in Lysogeny broth (LB) medium supplemented with corresponding antibiotics.

Preparation of the whole-cell biocatalysts with ethanol pretreatment. E. coli ML03 harboring plasmid pCJ02 was grown at $37^{\circ} \mathrm{C}$ for $12 \mathrm{~h}$ with $250 \mathrm{rpm}$ shaking in $2 \mathrm{~L}$ flask containing $240 \mathrm{~mL} \mathrm{LB}$ with $100 \mu \mathrm{m} /$ $\mathrm{mL}$ ampicillin. When the optical density $\left(\mathrm{OD}_{600}\right)$ of 0.6 was reached, ethanol and $0.5 \mathrm{mM}$ IPTG both were added, and the culture was continued at $20^{\circ} \mathrm{C}$ for $16 \mathrm{~h}$. In order to improve the biocatalytic efficiency, the concentrations of ethanol pretreatment were also studied. The influence of the different concentrations (i.e., $1 \%, 2 \%, 3 \%, 4 \%$ and $5 \%)$ of ethanol pretreatment on 5AVA production were discussed. Moreover, the effects of different types of metal additions (i.e., $\mathrm{Fe}^{2+}, \mathrm{Mn}^{2+}, \mathrm{Mg}^{2+}, \mathrm{Mo}^{2+}, \mathrm{Co}^{2+}, \mathrm{Ca}^{2+}, \mathrm{Zn}^{2+}, \mathrm{Cu}^{2+}$ and $\mathrm{Fe}^{3+}$ at constant concentrations of $3 \mathrm{mM}$ ) on yield were also investigated.

Conditions and scale-up of bioconversions. For 5AVA bioconversion, the cells were firstly harvested by centrifugation at $10,000 \mathrm{rpm}$ for $10 \mathrm{~min}$ after $16 \mathrm{~h}$ culture, then washed with potassium phosphate buffer (PKB, $50 \mathrm{mM}, \mathrm{pH} 8.0)$ twice, and then resuspended in $2 \mathrm{~mL}\left(\mathrm{OD}_{600}=40\right)$ reaction mixture containing $5 \mathrm{~g} / \mathrm{L}$ of L-lys $\mathrm{HCl}$. The bioconversion reactions were performed at $37^{\circ} \mathrm{C}$ and $\mathrm{pH} 8.0$, with $250 \mathrm{rpm}$ shaking for $12 \mathrm{~h}$. For the scale-up of bioconversion, the cell culture was concentrated, and suspended in $400 \mathrm{~mL}\left(\mathrm{OD}_{600}=80\right) \mathrm{PKB}$ buffer with $40 \mathrm{~g} / \mathrm{L}$ of L-lys $\mathrm{HCl}$. Other reaction conditions include: $25 \% \mathrm{NH}_{4} \mathrm{OH}$ was used to adjust the $\mathrm{pH}$ value to 8.0 ; aeration rate was set as $1 \mathrm{vvm} ; 30 \mathrm{~g} / \mathrm{L}$ of $\mathrm{L}$-lys $\mathrm{HCl}$ was added after $12 \mathrm{~h}$ bioconversion; additional L-lys $\mathrm{HCl}$ was added after $24 \mathrm{~h}$ bioconversion.

Analytical procedures. The optical density was determined by using an Ultrospec ${ }^{\mathrm{TM}} 2100$ pro UV/visible spectrophotometer (USA). Extracellular L-lys and 5AVA were quantified using a high performance liquid chromatography (HPLC) system (1260 series, Aglient Co., Ltd, CA, USA) equipped with a UV detector. To monitor the concentrations of 5AVA and L-lys, the method of phenyl isothiocyanate (PITC), described in our previous 

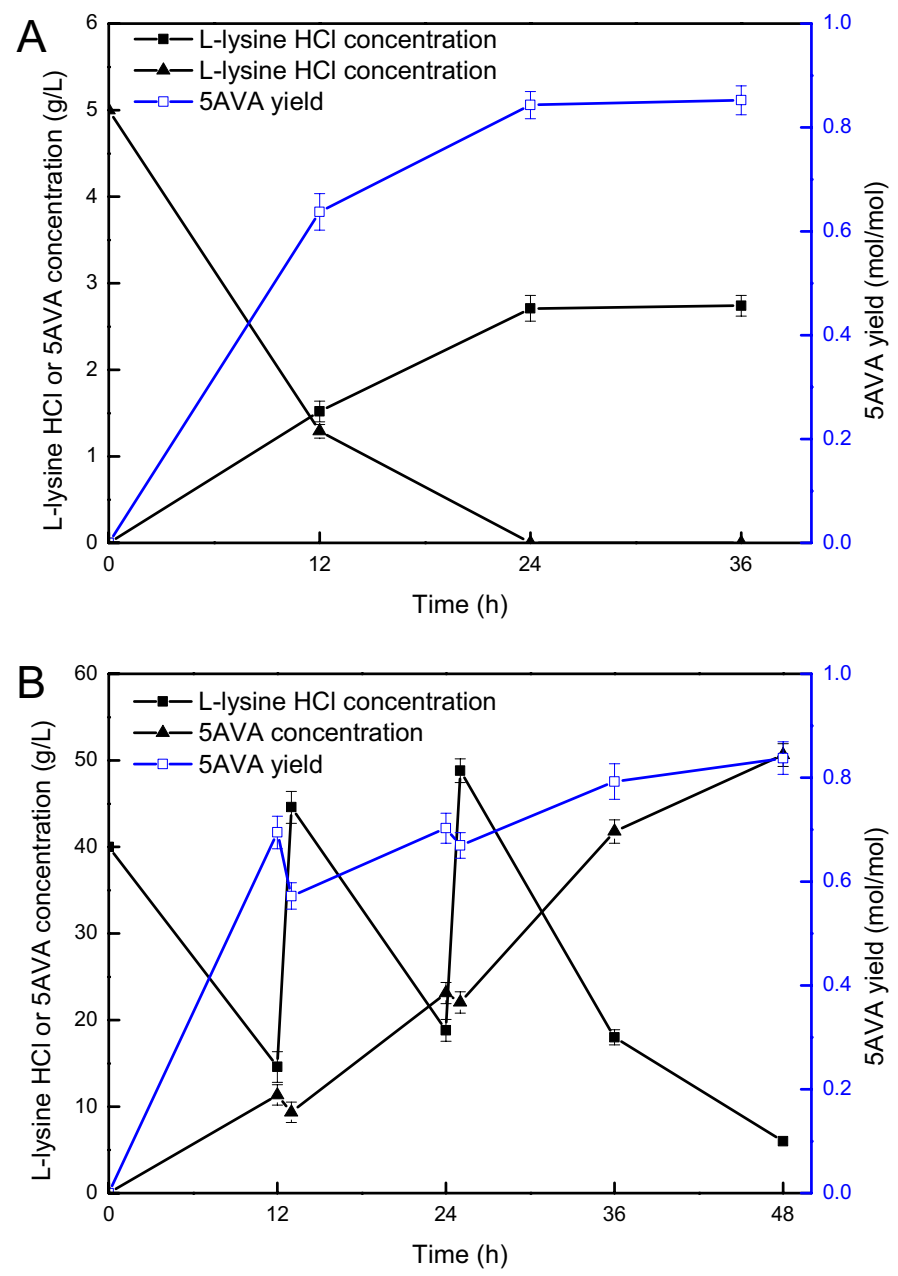

Figure 6. (A) Time profiles of 5AVA production were investigated by engineered whole-cell biocatalysts CJ02RaiP. The experiments were conducted at $5 \mathrm{~g} / \mathrm{L} \mathrm{L}$-lysine $\mathrm{HCl}, 4 \%$ ethanol pretreatment, $37^{\circ} \mathrm{C}, 3 \mathrm{mM} \mathrm{Mg}^{2+}$, pH 8.0 and $200 \mathrm{rpm} .10 \mathrm{mM} \mathrm{H}_{2} \mathrm{O}_{2}$ was added after reaction $8 \mathrm{~h}$. Values and error bars represent the mean and the standard deviation of triplicate cultivations. (B) Fed-batch strategy for the production of 5AVA by engineered whole-cell biocatalysts CJ02RaiP in a $400 \mathrm{~mL}$ reactor. The experiments were conducted at $100 \mathrm{~g} / \mathrm{L}$ L-lysine $\mathrm{HCl}, 4 \%$ ethanol pretreatment, $37^{\circ} \mathrm{C}, 3 \mathrm{mM} \mathrm{Mg}^{2+}$, pH 8.0 and $200 \mathrm{rpm} .10 \mathrm{mM} \mathrm{H}_{2} \mathrm{O}_{2}$ was added after reaction $8 \mathrm{~h}$. Data are means $\pm \mathrm{SD}(\mathrm{n}=3)$.
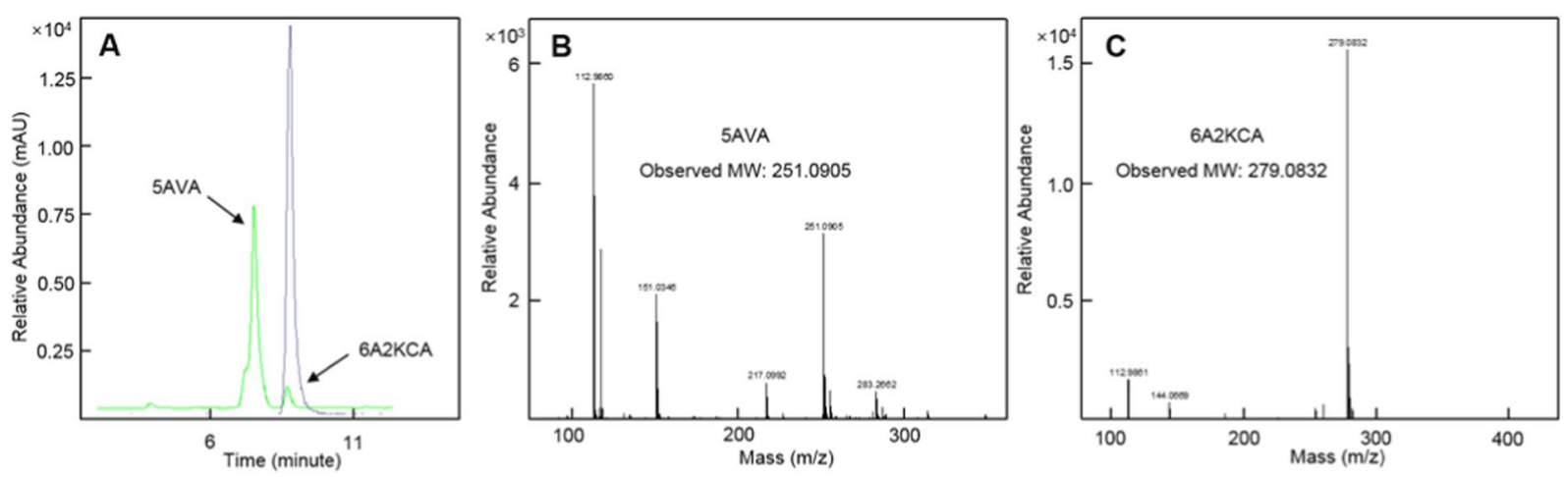

Figure 7. LC-MS confirmation of 5AVA and 2K6AC biosynthesis by whole-cell biocatalysts CJ02RaiP. (A) HPLC results of 5AVA and 2K6AC. (B) Mass spectrum of 5AVA. (C) Mass spectrum of 2K6AC. Samples were derived with phenyl isothiocyanate (PITC) for LC-MS analysis. 5AVA, 5-Aminovalerate. 2K6AC, 2-Keto-6aminocaproate. 
article, was adopted in this work ${ }^{10}$. Quantitative determination of $2 \mathrm{~K} 6 \mathrm{AC}$ was not performed due to the lack of its standard substrate. For liquid chromatography-mass spectrometry (LC-MS) identification of 5AVA and 6A2KCA, exact mass spectra was explored with a Bruker micrOTOF-Q II mass spectrometer, using the time of flight (TOF) technique as well as equipped with an ESI source operating in negative mode (Burker Co., Ltd, USA). The intermediate 2K6AC and 5AVA were qualitatively verified by LC-MS (see Fig. 7). As shown in Fig. 7A, the approximate retention time of 5AVA and $2 \mathrm{~K} 6 \mathrm{AC}$ was 7.2 and $8.9 \mathrm{~min}$, respectively. According to Fig. $7 \mathrm{~B}, \mathrm{C}$, the [M-H] $]^{-}$of 5AVA and 2K6AC were 251.0905 and 279.0832, respectively.

\section{Data availability}

The datasets generated during the current study are available from the corresponding author on reasonable request.

Received: 4 October 2019; Accepted: 31 December 2019;

Published online: 22 January 2020

\section{References}

1. Tsuge, Y., Kawaguchi, H., Sasaki, K. \& Kondo, A. Engineering cell factories for producing building block chemicals for bio-polymer synthesis. Microb. Cell Fact. 15, 19, https://doi.org/10.1186/s12934-016-0411-0 (2016).

2. Zhang, J. et al. Application of an Acyl-CoA Ligase from Streptomyces aizunensis for Lactam Biosynthesis. ACS Synth. Biol. 6 , 884-890, https://doi.org/10.1021/acssynbio.6b00372 (2017).

3. Hong, Y. G. et al. Production of glutaric acid from 5-aminovaleric acid using Escherichia coli whole cell bio-catalyst overexpressing GabTD from Bacillus subtilis. Enzyme Microb. Technol. 118, 57-65, https://doi.org/10.1016/j.enzmictec.2018.07.002 (2018).

4. Adkins, J., Jordan, J. \& Nielsen, D. R. Engineering Escherichia coli for renewable production of the 5-carbon polyamide buildingblocks 5-aminovalerate and glutarate. Biotechnol. Bioeng. 110, 1726-1734, https://doi.org/10.1002/bit.24828 (2013).

5. Liu, P. et al. Enzymatic production of 5-aminovalerate from L-lysine using L-lysine monooxygenase and 5-aminovaleramide amidohydrolase. Sci. Rep. 4, 5657, https://doi.org/10.1038/srep05657 (2014).

6. Eggeling, L. \& Bott, M. A giant market and a powerful metabolism: L-lysine provided by Corynebacterium glutamicum. Appl. Microbiol. Biotechnol. 99, 3387-3394, https://doi.org/10.1007/s00253-015-6508-2 (2015).

7. Ying, H. et al. Expanding metabolic pathway for de novo biosynthesis of the chiral pharmaceutical intermediate L-pipecolic acid in Escherichia coli. Microb. Cell Fact. 16, 52, https://doi.org/10.1186/s12934-017-0666-0 (2017).

8. Joo, J. C. et al. Production of 5-aminovaleric acid in recombinant Corynebacterium glutamicum strains from a Miscanthus hydrolysate solution prepared by a newly developed Miscanthus hydrolysis process. Bioresour. Technol. 245, 1692-1700, https://doi. org/10.1016/j.biortech.2017.05.131 (2017).

9. Jorge, J. M. P., Perez-Garcia, F. \& Wendisch, V. F. A new metabolic route for the fermentative production of 5-aminovalerate from glucose and alternative carbon sources. Bioresour. Technol. 245, 1701-1709, https://doi.org/10.1016/j.biortech.2017.04.108 (2017).

10. Cheng, J. et al. Enhanced 5-aminovalerate production in Escherichia coli from L-lysine with ethanol and hydrogen peroxide addition. J. Chem. Technol. Biotechnol. 93, 3492-3501, https://doi.org/10.1002/jctb.5708 (2018).

11. Park, S. J. et al. Metabolic engineering of Escherichia coli for the production of 5-aminovalerate and glutarate as C5 platform chemicals. Metab. Eng. 16, 42-47, https://doi.org/10.1016/j.ymben.2012.11.011 (2013).

12. Shin, J. H. et al. Metabolic engineering of Corynebacterium glutamicum for enhanced production of 5-aminovaleric acid. Microb. Cell Fact. 15, 174, https://doi.org/10.1186/s12934-016-0566-8 (2016).

13. Rohles, C. M., Giesselmann, G., Kohlstedt, M., Wittmann, C. \& Becker, J. Systems metabolic engineering of Corynebacterium glutamicum for the production of the carbon-5 platform chemicals 5-aminovalerate and glutarate. Microb. Cell Fact. 15, 154, https:// doi.org/10.1186/s12934-016-0553-0 (2016).

14. Pukin, A. V., Boeriu, C. G., Scott, E. L., Sanders, J. P. M. \& Franssen, M. C. R. An efficient enzymatic synthesis of 5-aminovaleric acid. J. Mol. Catal. B: Enzym. 65, 58-62, https://doi.org/10.1016/j.molcatb.2009.12.006 (2010).

15. Cheng, J. et al. Production of nonnatural straight-chain amino acid 6-aminocaproate via an artificial iterative carbon-chainextension cycle. Metab. Eng. 55, 23-32, https://doi.org/10.1016/j.ymben.2019.06.009 (2019).

16. Liu, Z. et al. In Vitro Reconstitution and Optimization of the Entire Pathway to Convert Glucose into Fatty Acid. ACS Synth. Biol. 6, 701-709, https://doi.org/10.1021/acssynbio.6b00348 (2017).

17. Lin, B. \& Tao, Y. Whole-cell biocatalysts by design. Microb. Cell Fact. 16, 106, https://doi.org/10.1186/s12934-017-0724-7 (2017).

18. Thakur, N. et al. Biotransformation of 4-hydroxyphenylacetonitrile to 4-hydroxyphenylacetic acid using whole cell arylacetonitrilase of Alcaligenes faecalis MTCC 12629. Process. Biochem. 73, 117-123, https://doi.org/10.1016/j.procbio.2018.07.012 (2018).

19. Li, H. H. et al. $\beta$-alanine production using whole-cell biocatalysts in recombinant Escherichia coli. Mol. Catal. 449, 93-98, https:// doi.org/10.1016/j.mcat.2018.02.008 (2018).

20. Cui, X. et al. Efficient glutathione production in metabolically engineered Escherichia coli strains using constitutive promoters. J. Biotechnol. 289, 39-45, https://doi.org/10.1016/j.jbiotec.2018.11.001 (2018).

21. Wang, X., Cai, P., Chen, K. \& Ouyang, P. Efficient production of 5-aminovalerate from L-lysine by engineered Escherichia coli whole-cell biocatalysts. J. Mol. Catal. B: Enzym. 134, 115-121, https://doi.org/10.1016/j.molcatb.2016.10.008 (2016).

22. Park, S. J. et al. High-level conversion of L-lysine into 5-aminovalerate that can be used for nylon 6,5 synthesis. Biotechnol. J. 9, 1322-1328, https://doi.org/10.1002/biot.201400156 (2014).

23. Li, Z. et al. Overexpression of transport proteins improves the production of 5-aminovalerate from L-lysine in Escherichia coli. Sci. Rep. 6, 30884, https://doi.org/10.1038/srep30884 (2016).

24. Chhetri, G., Kalita, P. \& Tripathi, T. An efficient protocol to enhance recombinant protein expression using ethanol in Escherichia coli. MethodsX 2, 385-391, https://doi.org/10.1016/j.mex.2015.09.005 (2015).

25. Chhetri, G., Pandey, T., Chinta, R., Kumar, A. \& Tripathi, T. An improved method for high-level soluble expression and purification of recombinant amyloid-beta peptide for in vitro studies. Protein Expr. Purif. 114, 71-76, https://doi.org/10.1016/j.pep.2015.05.015 (2015).

26. Thomas, J. G. \& Baneyx, F. Divergent effects of chaperone overexperssion and ethanol supplementation on inclusion body formation in recombinant escherichia coli. Protein Expr. Purif., 11 (1997).

27. Zheng, H. et al. Ethanol effects on the overexpression of heterologous catalase in Escherichia coli BL21 (DE3). Appl. Microbiol. Biotechnol., https://doi.org/10.1007/s00253-018-9509-0 (2018).

28. Yu, Z. et al. High level extracellular production of a recombinant alkaline catalase in E. coli BL21 under ethanol stress and its application in hydrogen peroxide removal after cotton fabrics bleaching. Bioresour. Technol. 214, 303-310, https://doi.org/10.1016/j. biortech.2016.04.110 (2016).

29. Cheng, J. et al. An economically and environmentally acceptable synthesis of chiral drug intermediate L-pipecolic acid from biomass-derived lysine via artificially engineered microbes. J. Ind. Microbiol. Biotechnol. 45, 405-415, https://doi.org/10.1007/ s10295-018-2044-2 (2018). 
30. Kloss, R. et al. Catalytically active inclusion bodies of L-lysine decarboxylase from E. coli for 1,5-diaminopentane production. Sci. Rep. 8, 5856, https://doi.org/10.1038/s41598-018-24070-2 (2018).

31. Steczko, J., Donoho, G. A., Dixon, J. E., Sugimoto, T. \& Axelrod, B. Effect of ethanol and low-temperature culture on expression of soybean lipoxygenase L-1 in Escherichia coli. Protein Expr. Purif. 2, 221-227 (1991).

32. Kashlev, M. V., Gragerov, A. I. \& Nikiforov, V. G. Heat shock response in Escherichia coli promotes assembly of plasmid encoded RNA polymerase $\beta$-subunit into RNA polymerase. Mol. Gen. Genet. 216, 469-474 (1989).

33. Tan, Z., Zhu, X., Chen, J., Li, Q. \& Zhang, X. Activating phosphoenolpyruvate carboxylase and phosphoenolpyruvate carboxykinase in combination for improvement of succinate production. Appl. Environ. Microbiol. 79, 4838-4844, https://doi.org/10.1128/ AEM.00826-13 (2013).

34. Liang, L. Y. et al. Increased production of succinic acid in Escherichia coli by overexpression of malate dehydrogenase. Biotechnol. Lett. 33, 2439-2444, https://doi.org/10.1007/s10529-011-0707-4 (2011).

35. Adina-Zada, A., Zeczycki, T. N. \& Attwood, P. V. Regulation of the structure and activity of pyruvate carboxylase by acetyl CoA. Arch. Biochem. Biophys. 519, 118-130, https://doi.org/10.1016/j.abb.2011.11.015 (2012).

36. Andreini, C., Bertini, I., Cavallaro, G., Holliday, G. L. \& Thornton, J. M. Metal ions in biological catalysis: from enzyme databases to general principles. J. Biol. Inorg. Chem. 13, 1205-1218, https://doi.org/10.1007/s00775-008-0404-5 (2008).

37. Tani, Y. et al. Heterologous expression of L-lysine alpha-oxidase from Scomber japonicus in Pichia pastoris and functional characterization of the recombinant enzyme. J. Biochem. 157, 201-210, https://doi.org/10.1093/jb/mvu064 (2015).

\section{Acknowledgements}

This work was supported by the National Key Research and Development Program of China (No. 2016YFC0906000); the funding from the National Natural Science Foundation of China (31870655); the Fundamental Research Funds for the Central Universities (Project No. 2018CDQYHG0010). We thank Ms. Jie Zhang for help with protein expression.

\section{Author contributions}

Wrote the paper: Jie Cheng. Prepared the figures: Jie Cheng, Qing Luo and Huaichuan Duan. Manuscript editing and review: Jie Cheng, Hao Peng and Yin Zhang. Conceived and designed the experiments: Jianping Hu and Yao Lu.

\section{Competing interests}

The authors declare no competing interests.

\section{Additional information}

Correspondence and requests for materials should be addressed to J.C., J.H. or Y.L.

Reprints and permissions information is available at www.nature.com/reprints.

Publisher's note Springer Nature remains neutral with regard to jurisdictional claims in published maps and institutional affiliations.

(c) (i) Open Access This article is licensed under a Creative Commons Attribution 4.0 International License, which permits use, sharing, adaptation, distribution and reproduction in any medium or format, as long as you give appropriate credit to the original author(s) and the source, provide a link to the Creative Commons license, and indicate if changes were made. The images or other third party material in this article are included in the article's Creative Commons license, unless indicated otherwise in a credit line to the material. If material is not included in the article's Creative Commons license and your intended use is not permitted by statutory regulation or exceeds the permitted use, you will need to obtain permission directly from the copyright holder. To view a copy of this license, visit http://creativecommons.org/licenses/by/4.0/.

(C) The Author(s) 2020 